\title{
Another Broken System: How the Adoption System in the United States Is Keeping Families Apart
}

\author{
Yvonne $\mathrm{Li}^{1}$ \\ ${ }^{1}$ Menlo School, Atherton, California, United States \\ Correspondence: Yvonne Li, Menlo School, Atherton, California, United States. E-mail: liyvonne5@gmail.com
}

Received: August 11, 2020 Accepted: September 10, 2020 Online Published: October 15, 2020

doi:10.5539/par.v9n2p58

URL: http://dx.doi.org/10.5539/par.v9n2p58

\begin{abstract}
At its best, the adoption system brings families together and gives children a chance at a happy and healthy life; however, as it turns out, like many other systems in the United States, the adoption system is entrenched with systemic racism that may negatively impact a child's life. In this paper, I examine the following questions: In what ways does the adoption process favor one race over the other? Who is imagined as the parent and the child in a transracial adoption? What has the public's response been when the parent is a person of color? I first look at scholarship related to transracial adoptions and the arguments around whether transracial adoptions are beneficial for the children. I discuss some deeply rooted problems in transracial adoptions that may have a long term impact on a child's life. I then outline my research methods, and finally, I discuss the results of my research. Ultimately, I argue that the adoption system, a system that is supposed to bring families together, is unintentionally keeping families apart with its regulations. In addition, I look into how some of the racist undertones in adoption policies have bled into what people imagine a family should look like.
\end{abstract}

Keywords: adoption policies, adoption system, interracial adoptions, racism, transracial adoption

\section{Introduction}

Watching the TV show "The Fosters" growing up allowed me to understand that family isn't defined by blood but rather by those who love and care for you. The show follows the Foster household and demonstrates how two adopted children, Callie and Jude, become part of the family. The parents are a lesbian couple Lena, who is biracial, and Stephanie, who is white. They had previously adopted two hispanic twins, and Stephanie had a son from a previous relationship. Watching this show and seeing the struggles that they faced sparked my interest in the adoption and fostering process and how individuals respond to a nontraditional family. With the current political climate in the U.S. and the Black Lives Matter movement, I was inspired to look at how race plays a factor in the adoption process. As I began to do preliminary research on adoption, I found that there was a significant difference between the proportion of white and non-white families that adopt children. This intrigued me, and I wanted to discover why this was the case. Was it systematic? Was it cultural? As I was researching, the terms "transracial adoptions" and "transnational adoptions" appeared repeatedly. When I looked into these types of adoption, I found that adoption companies were typically referring to a white family adopting a child of color, and there were few instances that were the other way around. This discovery led me to look at how the adoption process favors one race over the other, as well as who the imagined child and parent are in a transracial adoption. I also looked at different case studies and uncovered trends in how the public responds to a transracial adoption when the parents are black. The stories I found of black families who have adopted white children highlighted these trends and are especially relevant in a moment in which racial tensions are heightened.

\section{Academic Discussion about Transracial Adoptions}

On the surface level, transracial adoptions would seem beneficial for society as they provide children with homes that they otherwise would not have and make communities more diverse. However, many scholars also argue that transracial adoption brings a new set of issues.

One of the unseen benefits of transracial adoptions is that it helps get children out of the foster care system and into caring homes. Harvard Law Professor Elizabeth Bartholet (1991) argues that the foster system provides no permanency and notes that some foster parents are abusive and unfit parents (p. 1255). According to Psychology Today, approximately $28 \%$ of children in New York within the foster care system have experienced some sort of 
abuse while in the system (Babbel, 2012). This is significantly different from the value that Child and Family Services Review gives. They indicate that from January to September of 2000, the percentage of child abuse in the foster care system was $0.77 \%$ (Incidence of Child, n.d.,). Susanne Babbel (2012), a marriage and family therapist, suggests that the reason these two data sets do not align is that foster children are taught to be silent and a lot of the data that the child welfare system collects is incomplete and not representative. For example, Babbel interviewed Amy, an adult who had been a part of the foster care system for seven years, and she stated that 9 out of 10 of the foster care children that she encountered claimed to have been abused by a foster parent. However, many times the adoption process turns a blind eye to children's needs because of a lack of proper data and a desire to match the race of child and parent. Irv Fellner (1996), author of the journal article "Transracial Adoption" in the book Social Work, believes that safety, security, stability, nurturance and permanence should be the primary factors that adoption companies consider when matching children with their families, but often these crucial factors are overlooked because adoption agencies give race more weight (p. 432). By making transracial adoptions more common and reducing the stigma around race related adoptions, children will have a higher chance of being placed into a family that has the proper means to take care of them. Bartholet (1991) agrees with Fellner and adds that there needs to be more education around transracial adoption so that more people will feel inclined to participate in these types of adoptions (p. 1256).

Other scholars have argued that transracial adoption has extreme downsides that could potentially outweigh the benefits that Bartholet, Fellner and many others see. C. Lincoln Johnson (1976), Associate Professor of Sociology Emeritus at the University of Notre Dame, discusses how the clear inequality of power in the United States amongst people of different races can impact a child's life when not adopted into a family of their own race (p. 243). Johnson uses a white family adopting a black child as an example. The black child will experience the world differently than his or her white parents, and as a result, Johnson worries that the child will not be taught the necessary skills that they need to protect themselves when they go out into the oppressive, racist real world. He is also concerned that due to the family's lack of awareness of the struggles that their child will have to go through, the child may feel a sense of isolation and loneliness. In addition, transracial adoptions have received more visibility and increased during the last two decades, due to a decrease in the number of white babies getting put up for adoption and an increase in the number of white families looking to adopt (Simon, 1978, p. 135). Rita Simon (1978), a professor in the School of Public Affairs and the Washington College of Law at American University, argues that transracial adoptions started on the basis of benefitting white people rather than putting children in safe homes (p. 135). Although there are some clear benefits to transracial adoptions, the drawbacks are significant and could be potentially life threatening.

Some feminists scholars have looked at the topic of adoption in a different way. Instead of focusing on how the child is impacted, scholars such as feminist historian Laura Briggs draw attention to the impact an adoption, both interracial and transracial, can have on the biological mother. Although adopting is about putting a child into a family and a home, there is always another side: the mother who is giving up the child for adoption. Sometimes the mother gives up the child willingly, usually for the benefit of the child; however, it is not uncommon for a child to be taken away from his or her parents without their consent in international adoptions or even local adoptions involving a black mother (Briggs, 2012, p. 4) (Ye \& Gonzalez, 2015). These mothers may not even get the chance to fight for the right to keep their child, and often the adoptive parents are not aware of this (Briggs, 2012, p. 4). Briggs phrases it as the difference between "child stealing" and "child rescue". "Child stealing" is especially prominent in third world countries because of a lack of governmental regulation around adoptions, and as a result, children are being ripped away from their mothers. When wealthy white families in particular look to adopt transracially, it's common for them to go international. Briggs (2012) cautions families to do proper research on the adoption agency with which they are partnering with because illegal actions, like "child stealing," may happen behind the scenes, especially in international adoptions (p. 20).

\section{Methods}

To examine the racial discourses that occur during the adoption process, I looked at the different aspects of a person's life that adoption agencies consider when deciding whether or not a family would be a good adoptive family, and I considered, in particular, how these guidelines disproportionately impact people of color. I did so by looking at the following organizations: FC Adoption, Adoption.com, AdoptHelp, and AdoptionNetwork. I had first searched on Google for "Hispanic" + "Adoption" and "African American" + "Adoption," and although there were some great resources including blogs, there were no results from well-known news sources which could be generalized to a larger population. After hitting this road block, I decided to look at specific regulations in adoption that could potentially explain why fewer Hispanics and African Americans are adopting children. This approach yielded better results. I chose to focus my research on California and looked at the California adoption guidelines 
to see if any of them disproportionately impact one race over the other. Next, I turned to websites that specialize in transracial adoption in order to compare the rhetoric these websites use when discussing a white family adopting a non-white child versus a non-white family adopting a white child. The websites that I used for this are American Adoptions and Adopt US Kids. Finally, I consider four case studies in which the adoptive parents are people of color and adopt a child outside of their race. One of the families that I chose to include is the Jones-Baldwin family. They have a very unique story where their first child was biological, their next two children were adopted and were both black, and their most recent adopted child was white. This family has received a lot of press and openly talk about their struggles being a transracial family as a result of adoption. In some of the news articles about the families included in the case studies, there is a comments section where members of the public can share their opinions, so I also look at the commentary there to try to examine how the general public feels about that family and their adoption.

\section{Inequality in the Adoption Process}

When we look at the racial composition of the people who adopt children in the United States, it is clear that people of color are adopting significantly less than whites. The Early Childhood Longitudinal Study of the Kindergarten Class of 2010-2011, conducted by the U.S. Department of Education, found that African Americans make up 6\% of families who adopt while whites make up $77 \%$ (Zill, n.d.). When we compare these numbers with the distribution of races in the nation as a whole, African Americans make up $13 \%$ of the population while whites make up 60\% (2019 Census, 2019). These numbers are significantly different, leading to the question: is there systemic racism in the adoption system?

The simple and straightforward answer is yes. The U.S. was built on racism, and many of its social and cultural systems are inherently racist. In the adoption process, this systemic racism is seen in the policies and guidelines of adoption agencies.

Each state has different guidelines; however, for this research project, I focus on the regulations and policies of the California adoption process because California has consistently had the highest number of adoptions from 1999-2018 (Adoption Statistics, n.d.). Some of the basic requirements to be eligible to adopt in California include that the parent needs to be at least ten years older than the child who is being adopted and the home must be safe (What Are the California, n.d.). However, there are two other basic requirements that disproportionately affect people of color: the income requirement and the background check (What Are the California, n.d.). It has been shown time and time again that both Hispanics and Blacks receive significantly less income than white people. The median income for a white household in 2018 was $\$ 70,642$, but the median income for a hispanic household was $\$ 51,450$ and the median income for a black household was $\$ 41,361$ (Income and Wealth, 2019). The average black household received just under $\$ 30,000$ less annually than the average white household. To put that into perspective, the average cost of a meal at a restaurant for one person in the United States is $\$ 12.75$ (Hamm, 2020). Assuming a family of three, the average size of an American family, eats at a restaurant three times a day for seven days a week, the average price for food for one day would be $\$ 114.75$ (Duffin, 2019). An average white family could eat 768 more meals in a year than the average black family, assuming these conditions and no other expenses are paid. That means that the average white family could eat for 256 days more than the average black family. That is eight and a half months of food. There is clearly a disparity between the income of households of different races. As a result, the need to match a certain income requirement to qualify for adoption disproportionately affects people of color.

It is also no secret that African Americans are disproportionately accused of crime and disproportionately incarcerated. African Americans are five times more likely to be incarcerated than White Americans (Criminal Justice, n.d.). Although California adoption policies state that being a convicted criminal to a certain extent will not prevent anyone from being able to adopt, it may elongate the process. However, African Americans are disproportionately accused and convicted for crimes they did not commit (Stephens \& Possley, n.d., p. 4). For example, African American prisoners who are convicted of murder are $50 \%$ more likely to be innocent than other convicted prisoners (Stephens \& Possley, n.d., p. 4). If those people are released and choose to adopt, they will likely either face a longer wait time than necessary or be prevented from starting a family on illegitimate grounds.

This inequality extends past the policies to the adoption system as a whole. The two types of adoptions are public and private (How Much, n.d.). A public adoption, also known as foster-to-adoption, is when a child is taken away from their biological parents because of the parents' unfitness to provide for their child (Public Vs. Private, n.d.). The child is put into the foster care system and either stays with foster parents, in group homes, or another living situation; however, when and if the parents are rehabilitated, the child is expected to return to their biological family (Public Vs. Private, n.d.). In the case that one of the foster families feels a close connection with their foster 
child, they can choose to adopt them (Public Vs. Private, n.d.). This process is long and can take up to five years (Public Vs. Private, n.d.). It takes this long because in a public adoption, the biological parents have to give up their rights to the child, which many are not comfortable doing, especially if they are spending time rehabilitating for their child (Public Vs. Private, n.d.). The one extremely appealing factor about public adoptions is that they are typically cheaper, normally under $\$ 400$ (Public Vs. Private, n.d.).

On the contrary, a private adoption normally costs from $\$ 35,000$ to $\$ 50,000$ (Public Vs. Private, n.d.). Despite the high cost, private adoptions are more appealing than public adoptions in many ways. Private adoptions normally take six to twelve months because there is less uncertainty in regards to the birth parents (Public Vs. Private, n.d.). In a private adoption, the birth parents knowingly give up their rights to their child and hand their child to another family (Public Vs. Private, n.d.). Although open adoptions, where the biological parent can still have a relationship with their child, can occur, the biological parents do not have access to any legal rights for that child. Private adoptions are more common because there are fewer complications and less legal action needs to be taken, but it does come with a price tag (Public Vs. Private, n.d.).

When comparing these two types of adoptions, it is clear the dilemma that many people of color face. Because of the expensiveness of private adoptions, it is likely that they will lean towards public adoptions. However, for a public adoption, they have to deal with a long timeframe that many may not be willing to take on. In addition, public adoptions require a lot of time in court, and many people of color cannot take time off of work since a higher percentage work in essential jobs, like service and production jobs. As a result, many may choose not to adopt at all since neither of these two options satisfy their needs. These guidelines don't just affect people of color though. They also impact single parents and low-income families; however, those go beyond the scope of this paper.

\section{Imagined Parent and Child in Transracial Adoptions}

Although resources for transracial adoptions are available, there is a clear imbalance and bias towards white families adopting a non-white baby. On websites that offer guidance and tips on how to prepare for transracial adoptions, many of those tips assume that the family is white. For example, on the website Adopt US Kids, one of the tips is to "acknowledge racism" (Seven Suggestions, n.d.). Specifically, they advise parents to teach their children how to cope with and respond to racism (Seven Suggestions, n.d.). Although white people sometimes receive racist comments, the majority of the time racism is directed towards minority groups. Specifying that parents should teach their children to cope with racism leads the reader to understand that the child is a person of color and the parent is white. Moreover, the very first picture on the page is of a white mom with two black daughters (Seven Suggestions, n.d.). This further emphasizes the focus on white families adopting black children.

This bias is also seen in the type of resources provided for families. On the website American Adoptions, there are not only more resources for white families who are adopting a non-white child, but the resources that are provided are also more detailed and specific (25 Helpful, 2017). In total, when I accessed the site on July 31, 2020, there were nine resources for white families but only five resources for non-white families (25 Helpful, 2017). Of those resources, the ones for white families included more blogs and personal experiences from people who had transracially adopted (25 Helpful, 2017). The blogs and personal experiences came from people from different states and different experiences with adoption, but the common throughline was that they were all white (25 Helpful, 2017). The resources that were provided for non-white families were not comparable to those of the white families. Most of the resources were news stories about a family's experience and were often just one article, in comparison to the white families who had blogs and could continue to share stories and advice (25 Helpful, 2017). Almost all of the articles for non-white families were intended to encourage people to adopt transracially rather than provide insight or advice for those who have. As a result, these resources are not very useful for families who have already adopted, which is the majority of the website's audience (25 Helpful, 2017). Overall, the imbalance towards white families adopting transracially demonstrates that many adoption agencies still picture transracial adoptions as mainly occurring between white families and non-white children.

\section{Case Studies}

Each family experiences transracial adoption differently, depending on factors including a family's race, location, and the adoption agency they choose to work with. Here I look at four families who have all transracially adopted and their individual experiences as represented in the media. Each of these four families are black families who chose to adopt a white child, and while each family is from a different city, there are striking similarities in how the public has responded to these non-traditional families. In what follows, I will discuss these similarities, as well as the differences. 


\subsection{Taylor Family}

The first family is the Taylor family. Mik Taylor and her husband are black and have four children: a biological daughter, two adopted black sons and an adopted white son (Garlinghouse, 2020). With all of their adopted children, they went through public adoption. When going through that process with their two black sons, the Taylor family believes that the process went as smoothly as possible (Garlinghouse, 2020). This experience didn't hold true with their third adoption of their white son; they believe that they faced "discriminatory delays" (Garlinghouse, 2020). Some examples of those delays include "unnecessary deadline extensions," "more searches for a biological family member" and "unfinished (but racially-biased implied) comments from officials" (Garlinghouse, 2020). These extra obstacles demonstrate the intrinsic racism within not only the system but the people working in the system. The challenges didn't end there. After they were able to officially adopt their son, they endured comments made by passersby about their biracial family, including people assuming that Taylor was "her white son's babysitter, nanny, or stepmother" (Garlinghouse, 2020). Some have even assumed that she was a "mammy," a term used during slavery for black nannies caring for white children (Garlinghouse, 2020). Taylor tries not to let these comments affect her and instead tries to educate people and have open conversations with them. She hopes that people understand the "need to 'help a child of any color' find a forever family" (Garlinghouse, 2020).

\subsection{Farmer Family}

The Farmer family demonstrates a unique perspective since Barry Farmer not only grew up in the foster care system, but he is also a single parent (Garlinghouse, 2020). Farmer, who is black, knew that he wanted to be a foster parent, and at age 22, he fostered his first son, Jaxon, who is white (Fitzgerald, 2017). Jaxon and Farmer became family almost immediately. When it was time for Jaxon to move to his next home, both he and Farmer could not imagine their lives continuing without one another. As a result, Farmer adopted Jaxon at the age of sixteen (O'Kane, 2019). After adopting Jaxon, Farmer was unsure if he was ready to expand his family any further, but a few years later, Xavier, another white foster child, moved in with the Farmer family and was eventually adopted at the age of eleven (O'Kane, 2019). Finally, a few years later, Farmer adopted Jeremiah, also white, at the age of five (O'Kane, 2019). Since all his sons were white, Farmer felt it was important for them to have people who looked like them to relate to and look up to (O'Kane, 2019). He calls these people "racial mirrors" (O'Kane, 2019). Farmer has enrolled his three boys in a diverse school in a diverse community so that they can experience both white and black cultures (O'Kane, 2019). He looked to his white community to get tips on "his sons' haircare, skincare, and clothing" (Garlinghouse, 2020). One key point that makes Farmer's transracial adoption story successful is that he did not shy away from the racial differences between him and his sons, but rather embraced them and found resources to help both him and his sons navigate them.

However, he has faced criticism. When Farmer reached out to white people he knew for guidance and mentorship, he received some backlash, which he expected. He tried not to let those comments affect his and his children's lives and was able to find supportive white people. However, Farmer didn't expect to receive backlash from members of the black community after the Farmers' story went viral in 2014. Many of them claimed that Farmer must hate his blackness or didn't care about the people who look like him. Such comments further emphasize the idea that many are unable to accept this "untraditional" way of adopting, which is possibly a result of feeling frustrated that someone like Farmer, who has the resources to change a child's life, is choosing to help people that society already favors, white people, instead of the black children in the foster care system who are already disadvantaged by the color of their skin and are now even further disadvantaged because of their lack of parental influence. Despite these hurtful comments, Farmer and his family believe that the goal of the foster care and adoption system is to find a family and what makes a family is love. To them, love sees no color, which is why Farmer has chosen to stand by his sons and proudly share his story, hoping to influence and provide guidance to other families looking to contribute to the melting pot.

\subsection{Engleman Family}

Treka Engleman, another single black parent, had a similar experience to Farmer. Engleman's mom passed away when she was six years old, so Engleman never had someone "show her how to be a mom" (Engleman, n.d.). Growing up, she always knew she wanted to adopt, and in 2016, she began the process of fostering (Engleman, n.d.). She requested black or white children, which is less common to begin with (Engleman, n.d.). She was first matched with a white boy, Elijah Lee Hill, who was only a few days old (Menendez, 2020). Engleman took him in with open arms. The following year, she matched with Alexis and Mercedes, two white sisters (Menendez, 2020). A few years later, when Engleman discovered that adoption was an option, she immediately asked Alexis, Mercedes and Elijah, and "No one had to think of their answers; it was an immediate YES!" which demonstrates 
the deep connection that Engleman had formed with her children (Engleman, n.d.). Engleman legally adopted the three children on November 1, 2019, the first day of National Adoption Month (Richardson, 2020).

Like most other transracial families, their journey to becoming a family was not always smooth sailing and was not always accepted by those around them. In a blog post by Engleman, she talks about the weird stares that she gets from passersby and the questions she gets asked (Engleman, n.d.). One specific question that Engleman focuses on is "Oh, are you babysitting?" (Engleman, n.d.). She says that she always responds with "No, they are my kids" (Engleman, n.d.). In her blog, she emphasizes the fact that she has never called her children her foster kids, even when she was fostering them (Engleman, n.d.). She says that this is because "they are and always will be" her kids (Engleman, n.d.). People have come up to her and told her that she is turning her back on her culture and that she's continuing the "slave mentality" (Menendez, 2020). These comments reflect the challenge of moving past deeply held assumptions about these two races and their relationship with each other. Though these comments are hurtful, Englemen tries to focus on keeping her children happy and safe. Not all the feedback is bad, however. Many comments on articles about the Engleman family are about Engleman's bravery and her beautiful family. One person says, "What a wonderful person Treka must be" (Engleman, n.d.). Despite a few racist comments, the comment sections are filled with overwhelmingly positive comments. Engleman hopes to inspire people from all different walks of life to look into fostering children of all different backgrounds (Engleman, n.d.).

\subsection{Jones-Baldwin Family}

The Jones-Baldwin family, another transracial family, has received a lot of attention from the public. Kiea and Richardro (Rick), both black, have four children (Garlinghouse, 2020). Their first daughter Zaria, who is black, is from Kiea's previous relationship (Jones Baldwin Family, 2019). Kiea was initially hesitant about adopting because she worried that she wouldn't be able to love an adopted child the same way she loved Zaria (Jones Baldwin Family, 2019). Carly, their first black adopted child, changed that (Jones Baldwin Family, 2019). Zaria and Carly were best friends before Carly was adopted, and it was through Zaria that Kiea and Rick fell in love with Carly and ended up adopting her (Jones Baldwin Family, 2019). Aidan, also black, was Rick and Kiea's next adoption (Jones Baldwin Family, 2019). Though not intending to adopt a fourth child, Kiea was volunteering at a hospital to hold motherless babies skin to skin (Jones Baldwin Family, 2019). She expected to do skin to skin with a black or brown baby, but to her surprise, the nurse gave her a white baby named Princeton (Jones Baldwin Family, 2019). Although initially stunned, Kiea placed Princeton on her skin and immediately fell in love with him (Jones Baldwin Family, 2019). She started to go to the hospital every day to bond with him and eventually brought him home to the rest of the family (Jones Baldwin Family, 2019). This temporary three month stay turned into a permanent one. When the adoption became final, Kiea wanted to have a photoshoot to celebrate this important milestone in their family's life (Jones Baldwin Family, 2019). This photoshoot went viral and got them interviews on the Kelly Clarkson show, articles on major news outlets like Today.com and more. Another unique aspect of the Jones-Baldwin adoptions is that Kiea and Rick ensure that all of their children have connections with their biological parents so that they know their whole story and can establish their own identities (Jones Baldwin Family, 2019). Kiea likes to call the biological families their "bonus family" and refers to each of her adopted children as "our kid" (Jones Baldwin Family, 2019).

However, the Jones-Baldwin family have also received their fair share of hate. Though they live in a fairly diverse community in North Carolina, like most other African American transracial families they get awkward stares and the occasional question of "Are you the babysitter?" (Jones Baldwin Family, 2019). On The Kelly Clarkson Show, Kiea shared that she has had the cops called on her multiple times (Jones Baldwin Family, 2019). Once when she was in Tennessee having a photoshoot, the photographer asked if Princeton was her baby (Abrahamson, 2019). When Kiea responded yes, the photographer claimed that she had taken photos of this baby with his actual family two weeks prior (Abrahamson, 2019). Although clearly incorrect, the police arrived a few minutes later, and Kiea had to prove to officials that Princeton was, in fact, hers (Abrahamson, 2019). In August 2019, Kiea had a flat tire and pulled into a man's driveway (Abrahamson, 2019). Later, the man called officials claiming that she had stolen the car and the baby (Abrahamson, 2019). Again, she had to patiently prove that she in fact owned the car and was in custody of Princeton (Abrahamson, 2019). These actions once again indicate deeply-held prejudice and assumptions about African Americans in our society and show how those assumptions continue to negatively affect the black community. The Jones-Baldwin family has received supportive comments as well. Getting noticed by Kelly Clarkson and the outpouring of support by the public in the comment sections of articles and videos provides support for not only the Jones-Baldwin family, but the entire transracial adoption community. Kiea and her family started a YouTube channel, Raising Cultures, in the hope of breaking down racial barriers. She says, "I don't look at family as blood. I look at family as love" (Abrahamson, 2019). 
With the current Black Lives Matter movement, it becomes even more evident that the way these families have been treated is not a coincidence, but rather a result of systemic racism. The similarities in the public's response are indicative of the imagined child and parent in an adoption, as discussed previously. All the black mothers in these case studies have been asked if they are the nannies of their children, likely a result of how society and adoption agencies have portrayed what a mother and her child should look like. In addition, all of the families made it clear in interviews or news stories that they are advocates for nontraditional transracial families. The idea that these families need to continue to encourage people to look beyond race when adopting is further indicative of how systemic racism is embedded in the adoption system and society and how it is impacting families.

\section{Next Steps}

Adoptions bring together families from all different backgrounds and demonstrate what the "melting pot" of America looks like. No system in America is perfect, including the adoption one. White families adopt children at a disproportionately higher rate than people of color. I investigated this issue by looking at the internal policies and regulations that adoption agencies and the government have put in place, including making income levels and jail records part of the criteria for adoption. It became clear that these policies disproportionately affect people of color, and therefore, these policies should be considered when discussing the imbalance in those who are adopting. Beyond this, the entire system favors one race over the other, which can be seen by who adoption agencies and the public typically imagine as being the parent and the child in transracial adoptions. When looking at websites that provide advice to transracial families, it became clear that most people imagine the parents in a transracial adoption as being white and the child as a member of a racial minority. This can be seen through the types of advice the websites give, as well as how they market their websites. The case studies of families who are black and have adopted white children demonstrate the public's deeply held assumptions about transracial adoptions. Each family I looked at faced hate from their communities, which ranged from weird stares to uncomfortable questions to being unjustly questioned by the police. These examples show that it isn't just the adoption system that is broken, but also the community which supports and surrounds the system as well. As scholars continue to research this topic, it is critical that they look at how members of the public respond to these families and how individuals' responses differ in order to understand possible factors that play into this racist mindset. What makes each person's response different? How have institutions and systems within society influenced racist behaviors or mindsets? In light of the unrest in our nation right now in response to police brutality against black people, it is crucial that we take a hard look at how other systems, like the adoption system or the education system, also oppress people of color.

\section{References}

2019 census [Table]. (2019). U.S. Census Bureau. Retrieved from https://www.census.gov/quickfacts/fact/table/US/PST045219

25 helpful resources for transracial adoptive families. (2017, August 7). American Adoptions. Retrieved June 25, 2020, from https://www.americanadoptions.com/blog/25-helpful-resources-for-transracial-adoptivefamilies/

Abrahamson, R. P. (2019, September 9). What adopting a white baby taught one black family. Today. Retrieved June 25, 2020, from https://www.today.com/parents/african-american-couple-adopt-white-foster-babyt161976

Adoption statistics. (n.d.). Retrieved from https://travel.state.gov/content/travel/en/IntercountryAdoption/adopt_ref/adoption-statistics1.html

Babbel, S. (2012, January 3). The foster care system and its victims: Part 2. Psychology Today. Retrieved June 25, 2020, from https://www.psychologytoday.com/us/blog/somatic-psychology/201201/the-foster-caresystem-and-its-victims-part-2

Bartholet, E. (1991). Where do black children belong? The politics of race matching in adoption. University of Pennsylvania Law Review, 139, 1163-1256. https://doi.org/10.2307/3312364

Briggs, L. (2012). Somebody's children: The politics of transracial and transnational adoption. https://doi.org/10.1215/9780822394952

Criminal Justice Fact Sheet [Fact sheet]. (n.d.). NAACP. Retrieved July 31, 2020, from https://www.naacp.org/criminal-justice-fact-sheet/

Duffin, E. (2019, November 28). Average size of a family in the US 1960-2019. Statista. Retrieved June 25, 2020, from https://www.statista.com/statistics/183657/average-size-of-a-family-in-the-us/ 
Engleman, T. (n.d.). Love What Matters. Retrieved from https://www.lovewhatmatters.com/oh-are-youbabysitting-theyre-mine-im-a-30-year-old-single-black-woman-with-3-white-children-love-has-no-color-inmy-home-woman-adopts-1-boy-2-siblings-from-foster-care-love-is/

Fellner, I. (1996). Transracial adoption. Social Work, 41, 431-432.

Fitzgerald, B. (2017, December 1). Single dad adopts 3 sons: 'Fatherhood has brought me lots of joy'. CBS. Retrieved June 25, 2020, from https://localtvwtvr.wordpress.com/2017/12/01/barry-farmer-adoption/

Garlinghouse, R. (2020, May 13). Black parents who adopt white kids face unique challenges. Scary Mommy. Retrieved from https://www.scarymommy.com/five-black-parents-adopted-white-children/

Hamm, T. (2020, April 13). Don't eat out as often (188/365). The Simple Dollar. Retrieved June 25, 2020, from https://www.thesimpledollar.com/save-money/dont-eat-out-as-often/

How much does it cost to adopt A baby in california? (n.d.). Adoption Network. Retrieved June 25, 2020, from https://adoptionnetwork.com/california-adoption/how-much-does-adoption-cost-in-california

Incidence of child abuse and/or maltreatment. (n.d.). Retrieved from https://ocfs.ny.gov/connect/datawarehouse/incidence-of-abuse.php

Income and wealth in the United States: An overview of recent data. (2019, October 4). Peter G. Peterson Foundation. Retrieved June 25, 2020, from https://www.pgpf.org/blog/2019/10/income-and-wealth-in-theunited-states-an-overview-of-data

Johnson, C. L. (1976). Transracial adoption: Victim of ideology. Social Work, 21, 241-243. https://oi.org/10.1093/sw/21.3.241

Jones Baldwin Family. (2019, October 1). Biological father surprises family to thank them for adopting his son | The Kelly Clarkson Show (Interview by K. Clarkson) [TV series episode]. In The Kelly Clarkson Show.

Menendez, E. (2020, February 5). Black mum targeted by racists for adopting three white children. Metro UK. Retrieved June 25, 2020, from https://metro.co.uk/2020/02/05/black-mum-targeted-racists-adopting-threewhite-children-12185502/

O'Kane, C. (2019, July 16). Man who was once in foster care adopts 3 children of his own. CBS News. Retrieved June 25, 2020, from https://www.cbsnews.com/news/man-who-was-once-in-foster-care-adopts-3-childrenof-his-own/

Public vs. private adoption. (n.d.). AdoptHelp. Retrieved June 25, 2020, from https://www.adopthelp.com/publicvs-private-adoption/

Richardson, L. (2020, January 15). Black teacher who adopted three white foster children says 'love has no color in her home'. Blavity. Retrieved June 25, 2020, from https://blavity.com/black-single-mother-who-adoptedthree-white-foster-children-says-shes-been-asked-if-shes-babysitting

Seven suggestions for a successful transracial adoption. (n.d.). Adopt Us Kids. Retrieved June 26, 2020, from https://adoptuskids.org/adoption-and-foster-care/how-to-adopt-and-foster/envisioning-yourfamily/transracial-adoption

Simon, R. J. (1978). Black attitudes toward transracial adoption. Phylon, 39, 135-142. https://doi.org/10.2307/274508

Stephens, K., \& Possley, M. (n.d.). Race and wrongful convictions in the United States. Retrieved from http://www.law.umich.edu/special/exoneration/Documents/Race_and_Wrongful_Convictions.pdf

What are the california adoption requirements? (n.d.). Family Connections Christian Adoptions. Retrieved June 25, 2020, from https://www.fcadoptions.org/the-process/adoption-tips/ca-adoption-requirements.php

Ye, J., \& Gonzalez, S. (2015, May 26). Black mothers judged unfit at higher rate than white mothers in NJ. WNYC. Retrieved July 25, 2020, from https://www.wnyc.org/story/black-parents-nj-lose-custody-their-kids-moreanyone-else/

Zill, N. (n.d.). The changing face of adoption in the united states. Retrieved from https://ifstudies.org/blog/thechanging-face-of-adoption-in-the-united-states 


\section{Copyrights}

Copyright for this article is retained by the author(s), with first publication rights granted to the journal.

This is an open-access article distributed under the terms and conditions of the Creative Commons Attribution license (http://creativecommons.org/licenses/by/4.0/). 